\title{
The Position of the Jordanian Legislator on the Cancellation of the Administrative Decision for the Lack of Jurisdiction Defect
}

\author{
Jehan K. Al-Zubi \\ Faculty of Law, Al-Balqa Applied University, Center campus, Salt- 19117. Jordan
}

\begin{abstract}
This study aims at highlighting the position of the Jordanian legislator on the cancellation of the administrative decision for the lack of jurisdiction defect. It identifies the concept of lack of jurisdiction defect in the administrative decision and trying to explain and analyze the subject matter of the study including the legal articles and judicial rulings. It is necessary to respect the principle of legality in the activity of any member of the administrative authority through the direct powers assigned, and not to exceed the rules of distribution of jurisdiction or violating it. hence there must be a person who conducts legal acts and expresses their will in its name, and the administrative judiciary is the competent authority to control the jurisdiction in the administrative decision as the pyramid of Judiciary in Jordan.
\end{abstract}

Keywords: Jordanian legislator, Administrative decision, Jurisdiction defect, Jordan

DOI: $10.7176 / \mathrm{JLPG} / 90-11$

Publication date:October $31^{\text {st }} 2019$

\section{Introduction}

The administrative decision is an essential means to enable the administration, which enjoys privileges, the most important of which is that it is a national administrative authority, whether central or decentralized, to exercise the administrative competencies. It is characterized as an action aimed at creating a specific legal effect represented by amendment or limitation or cancellation. Hence, its difference of the contracts and material acts of the administration based on the existence of the agreement of wills, and the need for the consent of the other party (individuals).

In order for the decision to be valid, it must meet the conditions of validity approved by the Jordanian legislator, including jurisdiction, where the legislator has organized it as a cornerstone of the system; to protect individuals from the arbitrariness of the administration against their right and not to lose their rights and interests, and to know who is competent to issue it so that they can appeal to him easily and smoothly.

Administrative decisions issued by the administrative authority are important legal means by which the administration exercises its administrative activity and expresses its will for the interest of the public, due to many practical and theoretical problems raised by the administrative decision. However, when issuing such decisions, it shall adhere to the principle of legality so that their decisions are not subject to appeal by cancellation or compensation or both before the courts (Al-Samana, 2011).

If the administrative decision is flawed by defects, as the defect of lack of jurisdiction, violation of laws, regulations, procedures and form, or abuse of authority, then it is considered illegal and a reason to challenge the validity of the administrative decision. The legislator therefore requires the administration to issue its decision taking into account the jurisdiction, as a competent authority. Therefore, we shall discuss in this study the legal provisions stipulated by the Jordanian legislator regarding the issue of canceling the administrative decision due to the lack of jurisdiction by reference to the relevant laws.

\section{Research goals}

The objectives are determined by the importance of the subject in question, which is the position of the Jordanian legislator on the cancellation of the administrative decision for the lack of jurisdiction defect. therefore the objective of the study is to identify the concept of lack of jurisdiction in the administrative decision, and try to explain and analyze the subject matter of the study of legal and judicial provisions, and address whether There was a legislative deficiency that was committed by the Jordanian legislator with regard to the canceling the administrative decision for the lack of jurisdiction.

\section{Research importance}

The importance of this issue is due to frequent disagreement on cancellation of the administrative decision for lack of jurisdiction defect, and debate among competent bodies regarding its usefulness, hence it is necessary to shed light on the legitimacy of administrative decisions issued by a non-competent body under normal and exceptional circumstances and the extent of administrative control over them. The importance of research lies in identifying the cases where the decision is flawed of lack of jurisdiction and highlight the elements of jurisdiction in the administrative decision. 


\section{Research problem}

The principle of legality should be respected in the activity of any member of the administrative authority through the direct powers vested in him, and not to exceed the rules of distribution of jurisdiction and violating it. Some cases in Jordan that are filed at the administrative courts are contrary to the jurisdiction, so it suffers the problem of lack of jurisdiction defect whether under natural or exceptional circumstances. Therefore, the problem of the study is to attempt to investigate the rules and legal texts provided by the Jordanian legislator on the issue of the cancellation of the administrative decision due to lack of jurisdiction, by answering the following main question:

What is the position of the Jordanian legislator on the issue of canceling the administrative decision for the lack of jurisdiction?

\section{Research Methodology}

The researcher will rely on the analytical descriptive method based on reading and analyzing the legal texts in this regard and extrapolating the writers' opinions in the relevant legal studies and books and applying this to the Jordanian case.

\section{The concept of lack of jurisdiction in the administrative decision and its elements and characteristics}

The administrative decision is one of the most important aspects of the privileges of power that the administration enjoys and derives from public law. It is very important in administrative work. It is the essence of the administrative work itself. It represents the administration's disclosure of its individual will and intent with the aim of creating a specific legal position in the form determined by law, on the ground of its powers under laws and regulations.

The legislator did not set a specific definition of the administrative decision despite the reference to it in the various constitutional and legislative articles, despite the decisions of the administrative authority in a number of issues and competencies, as well as the being under the judicial control in various aspects (Al-Edwan, 2013).

The Jordanian High Court of Justice has defined it as a disclosure by the administration of its will to be bound by its authority under the laws and regulations, with a view to creating a legal effect, where possible and legally permissible, and to be motivated by public interest (Supreme Court of Jordan decision 1978), And that it is disclosure of its binding

will, through its authority under laws and regulations with a view to creating a particular legal effect, where possible, in a legal and legal manner (High Court of Justice, 2008).

While the Iraqi administrative judiciary defined it as a final administrative decision issued by an administrative authority and producing a legal effect (Decision of the General Assembly of the State Consultative Council, 2009).

Some defined it as a legal cat created by the administration by its sole will (Abdel Basset, 1997), and also defined as a unilateral act of a legal nature with administrative nature, the purpose of which is to influence the legal system or the rights and obligations of others without their consent (Labad, 2013).

The Egyptian Administrative Court defined it as a disclosure by the Administration of its binding will with its powers under the laws and regulations with a view to creating a certain legal effect for the public interest (Supreme Administrative Court of Egypt, 1967).

The Palestinian judiciary has defined it as a disclosure by the administration of its binding will, which has the authority under the laws and regulations to establish, amend or revoke a legal status when it is possible and legally permissible (High Court of Justice Decision in Gaza, 2012). This disclosure does not apply save as the decisions explicitly issued by the administration.

The French administrative judiciary has defined in more than one of its rulings the administration of its binding will with its public powers under the laws and regulations, and which would create, modify or cancel a certain legal status whenever possible and legally permissible. (Ismail, 2013).

Accordingly, the administrative decision cannot be taken unless the public administration or the public official is competent to issue it as a legal act taken by the competent administration, with its sole and binding will, with a view to creating a legal effect, with a view to establishing a new legal position ( bu'ali, 2005).

As a result of the diversity and huge functions of the modern state, the various social and economic responsibilities, rights and freedoms, the multiplicity of bodies, central and decentralized authorities, , sectors and administrative activities have led to the separation of powers within the same authority. Due to high significance of the existence of jurisdiction as an essential element in the administrative decision. The legislator Organizes it by itself and made it of the public order, in which it protects individuals from the arbitrariness of the administration in their rights and not to lose their interests (Al-Tamawi, 2006).

The validity of the administrative decisions and their legality means strict adoption of the provisions or principles of legality that prevail in the state. The integrity of the administrative decisions is related to the principle of legality in the state. This is a guarantee for safeguarding the rights of individuals and freedoms. If 
the administration does not implement the law, the decision becomes illegal and null. The legality is not limited to adherence of the administration to law only but also on the need to subject the administration to the duty to give some effectiveness to this legitimacy, in order to achieve the principle of transparency that should prevail and characterize its dealings with individuals (Masoud, 2017).

The term of jurisdiction shall be referred to the set of powers that allow the employee to perform certain functions within the public office. The decision must therefore be issued by the employee, which is determined by the legislator within the limits of his competence. The jurisdiction in the field of administrative decisions is the mandate of issuing them; Which may be considered as lacking the jurisdiction if issued by a person who has no mandate to issue them (Al-Tamawi, 1982).

The rules of jurisdiction help to determine responsibility, facilitate the direction of individuals in the departments of the governmental system, which becomes more complicated day by day, and protect the administration from the attack of another administration on its jurisdiction, and the limitation of powers of the employee on a particular type of behavior, allowed to achieve the good practice, (El Kantawy, 2011).

Each member of the administrative authority shall exercise the powers and functions entrusted to him only, whether he is an individual or a group of persons such as the boards and administrative committees and shall not exercise administrative work unless he is legally qualified according to the legal rules that regulate the powers of the administrative authority.

The jurisdiction in the administrative decision is of high importance and the ability to exercise a certain legal action. Therefore, the violation of the jurisdiction in administrative decision making is one of the defects that the administrative judiciary usually relies on to cancel the administrative decision as if it was not (Kanaan, 2000).

Jurisdiction is defined as the legal qualification enjoyed by individuals, organizations and administrative bodies which are what we call "administrative authorities" to conduct legal acts in the name of the general legal person (Hafez, 1993). The term "jurisdiction" refers to the set of powers issued by the person determined by the legislator within the limits of competence vested in him, which allow the employee to do some work in the framework of the public office, and is characterized of lack of jurisdiction if issued by those who have no mandate to issue them. Therefore, the lack of jurisdiction is not confined to the place and subject matter of the administrative decision, but also to cases in which the decision is issued by a person other than the person who has been appointed by the legal rules and if it has been issued by the employee concerned by law and in which the conditions for its validity are met (Shobaki, 2006).

If the administrative decision issued does not fall within the powers of the administrative authority that issued it, but falls within the powers of another administrative authority, and violates the rules of distribution of jurisdiction, then the administrative decision issued is characterized of the lack of jurisdiction error.

It is defined as a lack of legal qualification, to issue a specific administrative decision, i.e., the inability to make a specific administrative decision, should be issued by another employee or authority (El Kantawy, 2011).

The administrative decision issued by the administrative authority is subject to a lack of jurisdiction if it is taken or ordered to be taken outside such limits and controls. It will not considered legitimate if it is not based on a legal basis for issuing such decisions. The principle of legality must also be respected without violating the rules of jurisdiction. The administrative decision issued within the powers of the administrative authority issued by it and included within the powers of another administrative authority is not considered an infringement of the rules of jurisdiction and is considered as having lack of jurisdiction (Al-Samana, 2015). Therefore, the administrative decision shall be issued by those who have jurisdiction to issue it, from the members of the administrative Authority to be legitimate and true.

The basis of the defect of the lack of jurisdiction in the administrative decision to abuse negatively or positively the law of distribution of the jurisdiction (Shobaki 2006). The positive image of the lack of jurisdiction is achieved when the administrative authority takes an administrative decision that it is not entitled to take it, whereas the negative lack of jurisdiction is represented in cases where the competent authority refuses to issue an administrative decision falls under its jurisdiction and the administrative decision is issued in a negative manner and deserves to be revoked (Abdel-Fattah, 2009).

Shatanawi (2003) defines the lack of jurisdiction as the absence of legal qualification for a particular administrative decision, namely, the inability to make a particular administrative decision, because it should be issued by another employee or authority, while Kanaan (2006) defines it as inability to commence a particular legal act, which the legislator has made of another authority or individual. Which is the inability of any individual or administrative body to make an administrative decision, originally from the jurisdiction of another person or entity to be transferred by the legislator (Shobaki, 2006).

The characteristics of the lack of jurisdiction in the administrative decision is considered from the public order, and the main defect of the cancellation, and that the only defect related to public order, as it touches the foundations and rules of the distribution of jurisdiction and reforms radically, and is contrary to the principle of legality and consequent invalidity of the defective decision (Khalifa, 2003). 
The lack of jurisdiction may be territorial when it determines the geographical territory to the employee or body and exercises work outside this scope. It may be temporal if the employee started the powers of his position beyond the time limit for the exercise or non-duration of the post, such as a decision before taking office or after leaving office. The decision may be objective when the law defines the competence of the employee or the body in certain subjects. The decision is issued by a person who is not competent or in matters other than those specified by the law, such as the assault of an employee on the jurisdiction of another employee in a similar job or in parallel, or violation of powers of a president or chief of body by one of its employees or the assault of the executive authority on the powers of the legislative authority or judicial authority . in terms of the defect of form and procedures, the legislator has defined a set of formal rules and procedures that the employee must follow when making a decision. If he violates them, he is considered a defaulted and his conduct is considered to be flawed in form and procedures, which requires its cancellation. The procedures mean the various processes under which the administrative decision passes since the preparation to the pre-formulation in the final form. the defect of the lack of jurisdiction violating the law is represented in the case of failure of the administration to apply the legal rule or refuse to implement the obligations imposed upon it. This shall be done when it is obliged to carry out a specific act or conduct. If it takes a position to comply with this obligation, it is committed a contravention of the law which makes its decision null and void. The examples of this case when the administration refuses to grant a license to an individual despite the fulfillment of all legal requirements, or to refrain from appointing in one of the current positions in the order of merit of the candidates who succeeded in the competition to fill these positions (Haniyeh, 2008).

\section{The position of the Jordanian legislator on the issue of canceling the administrative decision for the lack of jurisdiction}

If the jurisdiction in the administrative decision is the ability and capacity granted by the law to the man of administrative authority in order to issue an administrative decision, this jurisdiction adheres to an objective, personal, temporal or spatial element. The legislator is the one who creates jurisdiction and determines who is qualified to exercise it in the light of constitutional rules. It shall not be lawful unless approved by the legislator.

For example, the Supreme Court of Jordan (2008) ruled that: Article 8 / b of the provisional Public Universities Law No. 42 of 2001 states that the legislator has given the president of the university, having specified his powers exclusively, to entrust, in part, The Vice-Presidents, the Deans or the Directors of the University , each under his / her duties, and thus the authorization is partial and limited in duration, meaning that he has not granted the President the right to make any of these persons replace him and transfer all his powers to him (Al-Qbealat, 2010).

The decision to consider administrative contracts and the ensuing disputes arises from the jurisdiction of the Supreme Court of Justice, which is provided by the legislator exclusively with the provisions of Article 9 of Law No. 12 of 1992 and its amendments, as stated in a decision of the Jordanian Supreme Court of Justice in 2011.

The Supreme Court of Justice has considered jurisdiction as a major part of the administrative decision. Violating the rules of jurisdiction, shall make the administrative decision null and void, as stipulated in Article 10 (a) of the Jordanian Employees' of the Civil Retirement Law and its amendments No. (34) for the year 1959. The decision to retirement of any employee if he/she completed the period prescribed in Article (15) of the said pension law shall be by a decision of the Council of Ministers. The employee of the Greater Amman Municipality shall be referred to retirement by a decision of the Council of the GAM which has the same powers of the Council of Ministers for this purpose.

The Supreme Court of Justice, for example, (2010), for example, stated that: "If an employee is absent for ten consecutive days without lawful leave and without lawful excuse, then termination of his services is in accordance with the provisions of section $169(\mathrm{~A} / 2)$ of the civil service system" Issued by the Minister of Culture is in accordance with the provisions of Article (55/A) of the Civil Service Law, since he has the authority and jurisdiction to issue such a decision, and since the administrative decision is valid and based on a rationale reason unless proven otherwise.

\section{Previous studies}

The study of (Albisony, Amal, (2017), aimed to emphasize the provisions of the case of canceling the administrative decision of the defect of non-jurisdiction in Palestine, comparing it with Egypt and France with an unpublished master thesis, the Islamic University- Gaza, where the descriptive approach used comparative analysis. The Palestinian Administrative Judiciary distinguished its decisions between the conditions of validity of the administrative decision and its pillars and considered a condition of acceptance of the cancellation action in addition to the requirement of lifting them within the time specified by law and conditions related to the plaintiff and the lack of parallel appeal.

The (Al-Samana \& Sameer study (2015) study examined the disciplinary powers of both the administration and the judiciary towards civil servants who are subject to the Civil Service Law and who has the 
right to impose disciplinary penalties, as well as the penalties imposed on the public official if the disciplinary offense proved. the study concluded that the defect of jurisdiction in the administrative decision was always linked to the principle of separation of powers and the principle of legality, and therefore no authority may attack another authority.

Kantawi and Abdullah (2011) conducted a study aimed at stressing the essence of the administrative decision and its elements and its distinction from the lack of jurisdiction in the administrative decision and the statement of the exceptions thereto. The study showed the limitations and powers of restricted and discretionary management in issuing administrative decisions, And the extent of its commitment to the principle of legality in addition to the role of the judiciary in the control of the administrative decision to violate the lack of jurisdiction in the light of natural and exceptional circumstances.

\section{Conclusion}

The researcher considers that administrative decisions are generally directed to achieve the public interest.

In the event of a violation of the jurisdiction element of the administrative decision, this makes the administrative decision characterized of lack of jurisdiction when issuance of administrative decisions, and therefore the Supreme Court of Justice decides to cancel such decisions, and this has been deduced from the judicial decisions issued by the Supreme Court of Justice.

The lack of jurisdiction in the administrative decision is the only defect related to the public order, and therefore the legislator himself has set the rules of jurisdiction for the administrative decision. This means that the element of jurisdiction in the administrative decision is the most obvious element for the judge or the individual. The public administration cannot express its own will despite its personal legal capacity.

Therefore, it is necessary to have a person who acts according to the law and expresses its will in its name. The rules of jurisdiction determine the person or authority granted by the authority to express the will of the administration. The administrative judiciary is the competent authority to supervise the jurisdiction in the administrative decision as the head of the judicial authority pyramid in Jordan.

\section{Recommendations}

The judge shall, in considering the case before him, raise the defect of the lack of jurisdiction by himself, even if no action has been filed by one of the litigants.

The Jordanian High Court of Justice must adopt a specific opinion regarding the correcting of the decision having a defect of lack of jurisdiction because of there is a clear difference in its judicial rulings.

Administrative bodies and administrative officials must respect the principle of stages of the legal rule when issuing administrative decisions and avoid violating them so as not to be subject to cancellation or withdrawal.

The administrative judiciary must maintain and emphasize the supervisory role over the legality of the administrative decision's jurisdiction in ordinary and extraordinary circumstances.

This research study recommends the judiciary and administrative jurisprudence to investigate in depth the issue of the lack of jurisdiction in the administrative decision with the aim of reaching a clear and specific criterion that distinguishes the simple and serious lack of jurisdiction.

\section{References}

Al-Bassiouni, A., (2017), Rulings of the cancellation of Administrative Decision for the lack of Jurisdiction in Palestine (Comparative Study), Unpublished Master Thesis, Islamic University, Gaza.

Abdel Basset, M. (1997), The suspension of the implementation of the administrative decision, University Thought House, Alexandria.

Abdel-Fattah, A. (2009), Al-Wajiz in the administrative judiciary, Egypt: the new university publishing house.

Al-Edwan, R. (2013), The effectiveness of administrative decisions against individuals - comparative study between Jordan and Egypt, unpublished master thesis, Middle East University, Jordan.

Al-Samahneh, S. (2015), The Defect of lack of Jurisdiction and its Effect on Administrative Decision, Studies in al-Shari'a and Law Journal, 42 (2) . 779-791.

Al-Shatanawi, A. (2003), Al-Wajiz in Administrative Law, I 1, Amman: Dar Wael Publishing and Distribution.

Al-Tamawi, S. (2006), General Theory of Administrative Decisions, press7, Dar Al-Fikr Al-Arabi, Egypt.

Al-Tamawi, S. (1986), Al-Wajeez in the administrative decision, Ain Shams University Press, Egypt.

Al-Qbealat, H., (2010), Administrative law, administrative decisions, administrative contracts in the general conditions, and public office, press 1, 2, Amman: Dar Wael Publishing and Distribution.

Bu'ali, M. (2005), Administrative decisions, Dar Al-Ulum for publication and distribution.

Decision of the Supreme Justice Court in Gaza in the application no 26/2012 hearing 23/12/2012.

Decision of the Supreme Justice Court in Jordan announced in its session on 15/06/1978.

El Kantawy, Abdullah, (2011), Element of Jurisdiction in Administrative Decision, Unpublished Master Thesis, University of Abu Bakr Belqayd Tlemcen, Algeria 
Haniyeh, E. (2008), Defects of the Administrative Decision, Journal of Legal Forum, Issue 5, University of Mohammed Khudair / Bskra.

Ismail, F., (2013), Place jurisdiction for case cancellation (Study of the Algerian legislation and judiciary), unpublished master thesis, University of Haj Lakhdar, Algeria.

Kanaan, N., (2000), Administrative Law, Book II, 1, Amman: House of Culture for publication and distribution.

Kanaan, N, (2006), Administrative Judiciary, press1, Amman: House of Culture for publication and distribution.

Khalifa, A. (2003), Reasons of challenge of cancelling the administrative decision in the State Council jurisprudence, Dar Al-Hussein Press.

Labad, N. (2013). Al-Wajiz in Administrative Law, press1, Dar Al Majd Publishing and Distribution, Setif, Algeria.

Masoud, S. (2017), The elements of the legitimacy of administrative decision, unpublished Master thesis, University of Xian Ashour - Djelfa.

Ruling of the Supreme Administrative Court of Egypt in the appeal, No. 674, for the year 12, session 2/9/1967.

Shobaki, O. (2006), Administrative Judiciary, Amman: House of Culture for publication and distribution.

The decision of the general panel in the State Shura Council number 212/disc./cassation /2009

The Jordanian High Court of Justice (2008) Decision No. 55/2008, Adala Center Publications.

\section{The Author bio}

Jihan K. Al-zubi is an Assistant Professor of General Law in Faculty of Law at Al-Balqa Applied University. She was awarded her PhD in General Law in 2011. She is currently Assistant Dean for Students Affairs Law in Faculty of Law at Al-Balqa Applied University 